DOI https://doi.org/10.18551/rjoas.2018-01.08

\title{
THE EFFECT OF EXTERN AND INTERN ENVIRONMENT TOWARD BUSINESS STRATEGIES AND THEIR IMPACT TOWARD BUSINESS PERFORMANCE
}

\author{
Seo Amario Yohanes*, Hidayat Kadarisman, Sunarti \\ Faculty of Administrative Science, University of Brawijaya, Indonesia \\ *E-mail: arioseo07@gmail.com
}

\begin{abstract}
This study was done to see the effect of extern and intern environment toward business strategies and the performance of micro, small and medium enterprises. The population of this study was business owners in Bajawa Regency, Nusa Tenggara Timur Province, Indonesia, represented by 122 respondents as the samples of this study. The samples were chosen using a proportionate stratified random sampling. The data of this study were then analyzed using Partial Least Square technique. The result of this study shows that extern and intern environment have significant effects toward business strategies and performance as mediators.
\end{abstract}

\section{KEY WORDS}

Enterprise, extern environement, intern environment, business strategies, business performance.

Severe economic crisis that hit Indonesia in 1998 and 2009 is the proof of the importance of micro, small and medium enterprises (MSMEs) for the nations' economy. During the crisis, large and formal industries were severely impacted, yet MSMEs remained strong and saved the nation's economy. MSMEs were strong enough to support the production sector and employement. Small-scale and medium-scale enterprises aim at running business which also streng then the national economy at the same time based on the fair economy democracy. This understanding implies that MSMEs is a national factor to improve and develop the national economy since it involves a number of businessman who improve local potential based on the fair rule for anyone (Rio and Susiawati, 2016).

Recently, MSMEs receives an intensive attention from both government and nongovernment parties in relation to the tight competition in the global market, especially the competition among micro-scale and medium-scale enterprises (MSMEs). Within the tight competiton, MSMEs should be aware of any factor that might influence its performance including the environmental factor and business strategy.

Hubeis and Nijab (2014) mentioned that reformation of information and globalization lead to rapid and everchanging major changes in the environment which tend to be difficult to predict. As the impact, the competition becomes tighter and organizations face more complex issues. Regarding to the fact, it is necessary to make an analysis on the extern and intern conditions faced by businessman. Thus, business owners will grow awareness and understanding on the implications of the shifting condition to be able to compete in the market in the most effective way.

Solihin (2012) stated that extern environment allows businessman to identify various opportunities and theats, while the intern environment gives some insights about strengths and weaknesses. Another key factor in managing a business is the use of effective business strategies to win the market. Businessman is competing against each other to win the competiton. The attempts made to win over the competiton are referred as business strategies. According to Assauri (2013), business concepts and strategies are basicly attempts to relate certain stategy to the supremacies that can be obtained from the implementation of the strategy. This notion includes pattern of actions in implementing certain strategies to achieve certain target or expectation. Business strategy is an effort made to add uniqueness to business to win the market competition. The uniqueness can be 
achieved if a company uses unique ways in promoting the values of a superior product to the consumers.

This study was brought as an immediate response toward the tight market competition faced by business owners (MSMEs) in Bajawa regency, Nusa Tenggara Timur Province, Indonesia. The researchers suspected some issues related to the lack of innovation, improper business strategies and slow reaction toward changes in business environment. Owners of MSMEs business tend to play passive in promoting their goods and services because most of them chose to patiently and passively wait for the consumers to come and buy their products. This condition is intrigued the reseachers to conduct a deeper study on the dynamic business environment in Bajawa regency and its implication toward the use of certain business strategies in running certain business, as well as its implication toward the business performance. Bajawa regency is one of regencies in Ngada district, Nusa Tenggara Timur.

The fact that there were high numbers of owners whose business had not yet been legally registered in the Cooperative Department, MSMEs, Industrials and Trading Department in Ngada District. Based on the data, it has been known that only 174 people out of 458 business owners who have registered their enterprises. Another issue was related to the high number of micro enterprises while Bajawa regency is the central regency in Ndada district. The data released by the Cooperative Deartment, MSMEs, and Industry and Trade of Ngada District 2015 show that UMKM members were dominated by micro-scale business owners $(82.97 \%)$, small-scale business owners $(16.38 \%)$. There were only $0.66 \%$ of medium-scale business owners among them. Micro-scale business owners dominated the business activies in Bajawa regency as much as $82.97 \%$.

Regarding to the problems which have been stated above, some research questions are formulated as follow:

- Does extern environement have a significant influence on business performance?

- Does extern environement have a significant influence on business strategy?

- Does intern environement have a significant influence on business strategy?

- Does intern environement have a significant influence on business performance?

- Does business strategy have a significant influence on business performance?

\section{LITERATURE REVIEW}

Rapid changes in business environement require business owners to always make use of any opportunities and to keep making innovation. This condition is an impact of the right market competition in the business sector which appears to be an interesting issue for researchers all around the world to conduct their reseach on the business environment, business strategy and business performance. Previous research has provided references that help the researchers to determine the conceptual framework used in this study. Based on the predetermined conceptual framework, the orientation and the goal of the research can be determined.

Robbin (1994) mentioned that environment is related to any thing that is either directly or indirectly relevant for an organization in achieving its goals. In running a business, intensive interaction always occur between business owners and business environment since business and enviornement are mutual. Business runs in environment that provides qualified employees and resources in the production activities, besides the products of a company will always be sold back to the environment. On the other hand, the continuity and the usefulness of an environment also depend on the treatment given by the company itself.

Tan and Litschert (1996) mentioned that environment can be seen using two perspectives. First, due to the uncertainty of information, environment becomes a reliable source of information for a company. Second, environment is regarded as a rare and important source for a company to compete. David (2010) classified business environment into two major power; intern and extern. David (2010) stated that extern environment provides information related to opportunities which are beneficial for a company and threats that should be anticipated by a company. Wheelem and Hunger (2001) mentioned that intern 
environment basicly consists of; structure, culture, and resources. Hence, intern environment covers any factor that comes from the inside of a company including structure, cuture and any resources which potentially influence business performance. Those aspects might appear as strength or weakness for a company in running business activities.

Wheelen and Hunger (2001) explained that business strategy refers to a set of a designed comprehensive plan on how a company achieves its missions and goals by utilizing its competitiveness within a limited resource. David (2006) stated that strategy is a potential action that is decided by the upper management and a company's big amount of resource. Therefore, it can be concluded that streategy is an arranged long-term plan made by a company to achieve the goals of the company.

According to Mulyadi (1997), business performance can be periodically measured from the operational effectiveness of an organization, parts of an organization and the employees based on the target, standard and predetermined criteria that apply. Basically, an organization is run by human. Thus, organizational performance should be measured upon human behavior in running their roles in an organization. David (1997) also highlighted that performance is an achievement or results that are achieved by an organization and usually they are in the forms of positive results. Oganizational performance is important to measure since it provides data for the evaluation of the company and to control the company which result depends on each unit of an organization and the target set by the unit (Hunger dan Wheelen, 1996).

Wahyudi (1996) explained that extern environment is the potential strength from the outside of a company which has either direct or indirect influence on the company's performance. Meanwhile, Solihin (2012) mentioned that business environement aims at identifying any possible opportunities and threats. Thus, it can be concluded that extern environment refers to any kind of opportunities and threats that might influence an enterprise. The result of a study conducted by Hidayat (2003) indicates an influence of macro environmental factor toward marketing strategies and performance of a cement industry in Indonesia. Measurement on a company's performance is important for the evaluation and controlling process of a company. The measurement depends on how an organization unit is asseesed, and the goals of the organization (Hunger and Wheelen, 1996). A study conducted by Arifin (2007) showed that business environment has certain influence toward business strategy and competitiveness and it also also influences the performance of smallscale industries through the competitiveness strategy. Regarding the underlying theories and results of previous studies mentioned previously, the hypotheses of this study were formulated as follow.

H1: Extern Environement Significantly Influences Business Performance.

David (2010) stated that extern environment gives information related to any opportunities for a company and threats that should be anticipated by a company. In addition, Porter (1985) explained that a company might obtain its competitiveness by improving certain quality that can be offered to the consumers by conducting various strategies such as; offering lower price with better service for the consumers than other competitors. A study conducted by Banham (2010) stated that owners or managers of a business should have adequeate comprehension and choose appropriate strategies in responding the potential of extern environment. Tan and Litschert (1996) also mentioned that the characteristics of an environment influence the strategy and strategic orientation in which the use of different strategy results different performance. Regarding to the theories and the results of previous study, the hypothesis of this study was formulated as follows.

H2: Extern Environement Significantly Influences Business Strategy.

Wahyudi (1996) stated that in order to win a market competition, a company should make use of its resouces to identify the stregths and weaknesses to improve its competitiveness. Solihin (2012) also explained that business strategy should be made for certain business unit or for products, besides it should also emphasize on the improvement of products or services offered by a company within certain industry or market.

Sugiarto (2006) conducted a study which resulted to an interesting finding; competition in the environment gives negative influence toward small-scale industry, but gives positive 
influence toward business strategy. Whilst, business strategy has a positive and significant influence on the business performance. Edelman (2004) also proved that business strategy significantly influences the performance, and strategy also plays a role as the mediator between the resources and performance. Meanwhile, human resource also has a positive and significant influence toward the strategy and the quality of the consumer service. Business resources which were measured in this study included the human resources and organizational resources with stonger emphasis on the use of business strategy for innovation and service. Thus, the hypothesis of this study was formulated as follows.

H3: Intern Environment Significantly Influences Business Strategy.

Solihin (2012) explained that intern environment provides information that can be used to identify the strengths and weaknesses of a resource owned by a company and the intern business process of the company. Amirullah (2015) mentioned that intern environment refers to factors inside an organization that reflect the strengths and weaknesses of the organization. David (1997) added that performance is the achievement or results obtained by a company which usually are in the forms of positive results. The study conducted by Tan and Litschert (1996) on electronics industries in China indicates that environmental changes influence the business strategy, and the use of certain business strategy influences the business performance. Regarding to the explanation, the hypothesis of this study was formulated as follows.

H4: Intern Environment Significantly Influences Business Performance.

According to Mulyadi (1997), performance can be periodically measured through the operational effectiveness of an organization, parts of an organization and employees based on the predetermined targets, standards and criteria. Solihin (2012) then specified business strategy should be made for business unit or products, and the strategy must be meant to improve the competitiveness of the products or services offered by a company within a particular industry or segmented market. Maridjo (2004) found in his study that market orientation has a significant influence on the generic strategic and business performance. Meanwhile, Luo (1999) stated that environment influences the strategic orientation and it has certain implication toward the performance of small-scale business. The form of strategy which effectively improves the performance is innovation. Therefore, the hypothesis of this study was formulated as follows.

H5: Business Strategy significantly influences the Business Performance.

This study aimed at testing and explaining the influence of extern and intern environments toward business strategy and business performance of UMKM. Regarding to the explanation of the background of the study, theoretical background, and the results of previous studies, this research was employed using the model seen from Figure 1.

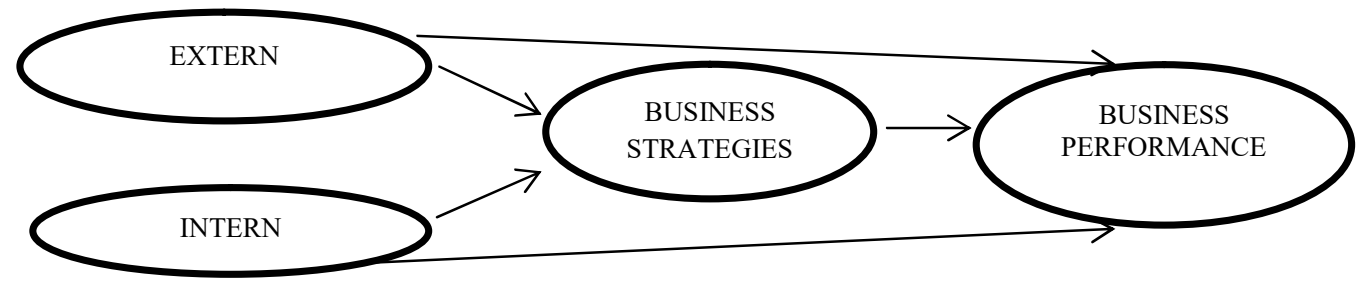

Figure 1 - The Research Model

\section{METHODS OF RESEARCH}

This study is an explanatory research which employed a quantitative approach. There were 122 UMKM owners from Bajawa Regency, Ngada District, NTT who participated as the samples of this study. The extern environment was measured using 10 items developed by Pearce II and Robinson Jr, (1997) and Wheelen and Hunger (1986). Intern environment was measured using 9 items proposed by Wheelen and Hunger (!996), Wahyudi (!996) and Amirullah (2012). The strategy was measured using 4 items which were developed by Porter (1980, 1985). Business performance was seen from 5 items as proposed by Mulyadi (1997), 
Munawir (2000) and Luo (1999). Partial Least Square (PLS) was used to analyze the data. The use of proportional stratified random sampling enabled the researcher to have stratified number of samples to represent population of certain strata (Rambat, 2015: 74) as presented in Table 1.

Table 1 - Sample Proportion in this Study

\begin{tabular}{|c|c|c|c|c|}
\hline NO & Regency & Population & Sampling Measrument & Number of Samples \\
\hline 1 & Bajawa & 19 & $\frac{19}{174} \times 122=13,22$ & 13 \\
\hline 2 & Tanalodu & 26 & $\frac{26}{174} \times 122=18,22$ & 18 \\
\hline 3 & Kisanata & 14 & $\frac{14}{174} \times 122=9,81$ & 4 \\
\hline 4 & Jawameze & 5 & $\frac{5}{174} \times 122=3,5$ & 18 \\
\hline 5 & Trikora & 26 & $\frac{26}{174} \times 122=18,22$ & 18 \\
\hline 6 & Lebijaga & 25 & $\frac{25}{174} \times 122=17,5$ & 3 \\
\hline 7 & Susu & 4 & $\frac{4}{174} \times 122=2,8$ & 20 \\
\hline 8 & Ngedukelu & 29 & $\frac{29}{174} \times 122=20,33$ & 18 \\
\hline 9 & Faobata & 26 & $\frac{26}{174} \times 122=18,22$ & 122 \\
\hline- & - & 174 & - & \\
\hline
\end{tabular}

\section{RESULTS AND DISCUSSION}

$\mathrm{H} 1$ : Extern environment has a positive, direct and significant influence toward business performance. Extern environment has a positive influence toward business performance with path coefficient of 0.2042 and $t$ statistic value 2.6589 greater than the table (1.960) and significant at $p<0.05$. Therefore, the null hypothesis is rejected and the hypothesis is accepted.

This result generally shows that the extern business environment in Bajawa Regency supports the business performance. It also implies that any change that occur to the extern environment would likely bring changes in the business performance. The society is known to be the most dominant indicator in which the products sold in the market have fulfilled the social values that apply in the society. Besides, this improvement is also resulted by the easiness in applying for capital support, active supports from the government in the form of trainings and business workshops, and the use of advanced technology to impove the production quality and better service quality.

H2: Extern Environment has a positive, direct and significant influence on business strategy. Extern environment is found to have a positive influence toward the business strategy at path coefficient of 0.3077 and $t$ value of 3.8303 greater than the table (1.960) and significant $(p<0.05)$. Thus, HO is rejected and the second hypothesis of this study is accepted.

This result indicates that any changes that occur on the economy, social, government and technology aspects influence business owners to repond to any kinds of opportunities and threats. Business owners in Bajawa Regency applied pricing strategy and price differentiation as the reactions toward changes that occurred in the extern environment.

H3: Intern environment has a positive, direct and significant influence toward Business Strategy. Intern environment positively influences business strategy at a coefficient value of 0.4994 and $t$ value of 6.2431 lesser than the t table (1.960), significant at $p<0.05 \%$. Those values are strong enough to reject the null hypothesis, which implies that intern environment plays a positive, direct and significant influence toward the business strategy. Therefore, the third hypothesis is accepted.

The hypothesis generally implies that business strategy applied by a business owner will run well if it is supported by good business environment. Thus, the more favorable the intern environment, the easier it is for a business owner to run the business. It can be inferred from the result of this study that business owners in Bajawa regency have optimally make use of the available resources in an organization by considering the easiness in 
conducting marketing activities and to apply for capital loan through pricing strategy and differentiation.

H4: Intern Environment has a positive, direct and significant influence toward Business Performance. Intern environment positively influences business performance at a coefficient value of 0,2246 and $t$ value 2,5458 lesser than the $t$ table (1.960), significant at $p<0.05 \%$. This result rejects the null hypothesis, which implies that intern environment plays a positive, direct and significant influence toward the business performance. Therefore, the fourth hypothesis is accepted.

The result of the measurement shows that the intern environment seen from its function in Bajawa regency has been considered good enough to support the business performance. The most dominant function of the intern environment is the marketing since the company is located in a strategic area in the central of the district, supported by adequate production function for it is easy to get the production materials. Moreover, employees in the company are competetent and huge amount of capital was available to support the business.

H5: Business Strategy has a positive, direct and significant influence toward Business Performance. Business Strategy positively influences business performance at a coefficient value of 0,4581 and $t$ value 5,0597 lesser than the $t$ table (1.960), significant at $p<0.05 \%$. This result rejects the null hypothesis, which implies that business strategy has a positive, direct and significant influence toward business performance. Therefore, the fifth hypothesis is accepted.

This result shows that the application of pricing strategy as the most dominant business strategy in Bajawa Regency gives positive contribution to the business performance including the effectiveness of the production process and the determination of competitive price. One of ways to measure a company's performance is by analyzing how the company responds or anticipates any change that occur in the environment by applying certain strategy to prevent the business from getting negatively affected by any change.

\section{CONCLUSION}

The result of this study to find the influences of extern and intern environment toward business strategy and business performance in Bajawa regency, Ngada district, Nusa Tenggara Timur supports the funding of some previous research done in Indonesia. This study has also proven that business environment in Indonesia is conducive enough for investors to run their enterprises. It is expected that the result of this study as well as the results of some previous studies enhance the motivation of the society to run their own business. National economic development and the advancement of a nation can be measured from the number of business owners in the country. Apart from that, enterprises in Indonesia especially MSMEs should consider some aspects, one of which is the way to implement appropriate business strategy as a response toward changes in the business environment. Business owners should also improve their capability in running their business. In this case, the government should act as a mediator in providing business trainings and workshops for the society. Business owners are also required to be aware of any changes that occur in the business context to be able to anticipate them by applying the best business strategy to maintain and improve the business performance. This study suffers from a weakness in which the samples aredominated by micro-scale bsiness owners. Besides, the scope of this study is relatively narrow and limited to only business owners who have legal business lisence. It is suggested that future researchers increase the ratio of the types of enterprises. Future researchers are also expected to conduct similar study with broader scope of the study to be able to generate the result of the study.

\section{REFERENCES}

1. Arifin. 2007. "Pengaruh Lingkungan dan Karakteristik Managerial terhadap Strategi Keunggulan Bersaing dan Industri Kecil (Study pada Idustri Kecil Ayaman Bambu Binaan Dinas Perindustrian Dan Perdagangan Provinsi Jawa Timur)". 
2. Amirullah.2015. Manajemen Strategi Teori-Konsep-kinerja. Penerbit Mitra Wacana Media. Jakarta.

3. Assauri, Sofjan. 2013. Strategic Management. Depok. Rajagrafindo Persada.

4. Banham Heather C. 2010). External Environmental Analysis For Small And Medium Enterprises (SMEs). Journal of Business \& Economic Research.

5. David, Fred. R, 2003. Strategi Managemen: Concept, 9th Edition, Pearson Education, New Jersey

6. David, Fred. R, 2010. Strategi Managemen: Concept, 12th Edition, Pearson Education, New Jersey, Salemba Empat, Jakarta.

7. David, Fred. R, 2006. Strategic Mangement 10th Editon, Pearce Education-Prentice Hall, New Jersey. Ichsan Setiyo Budi (penterjemah), 2006. Manajemen Strategis, Konsep edisi 10, Penerbit Salemba Empat, Jakarta.

8. Dinas Koperasi, UMKM, Perindustrian dan Perdagangan Kabupaten Ngada 2015

9. Edelman. 2004. "The Mediating Role Of Strategy on Small Dirm Performance.

10. Hidayat A. 2003. Pengaruh Lingkungan Makro, Lingkungan Industri dan Lingkungan Internal Terhadap Matketing Strategi dan Kinerja Perusahaan".

11. Hubeis Musa, Najib Mukhamad.2014. Managemen Strategik dalam Pengembangan Daya Saing Organisasi. PT Flex Media Komputindo. Jakarta.

12. Hunger, J.Q \& Wheelen, T.L. 1986. Strategic Management and Business Policy, 2th edition, Addison Weley Publishing Company, London.

13. Hunger, J.Q \& Wheelen, T.L. 1996. Strategic Management 5th edition, Addison Weley Publishing Company. Julianto Agung (penterjemah), 2003, Manajemen Stratergis, edisi kedua, Andi Offset, Yogyakarta.

14. Luo Yandong .1999. "Enviroment-Strategy-Performance relation in small Bussines in China: A case of Town-ship and village enterprise in Southem (TVE's China)". Journal of Small Business Management.

15. Maridjo. H . 2004. "Pengaruh Orientasi Pasar dan Strategi Generik terhadap Kinerja Perusahaan: Dengan Lingkunga Pemasaran Sebagai Variabel Moderator". Jurnal Ekskulsif.

16. Mulyadi. 1997. Akutansi Keuangan: Pendekatan Kuantitatif dan Kualitatif, Jilid 1, Bayumedia, Malang.

17. Munawir. (2000), Analisa Laporan Keuangan, Penerbit Liberty, Yogyakarta

18. Pearce J.A and R.B Robinson, 1997, Srategi Management Formulation, Implementation and Control, Fifty Edition, Burr Ridge, Illinois.

19. Porter, M.E., 1980, Competitive Strategy: Techniques for Analyzing Industri and Competitors. Three Free Press, New York.

20. Porter, M.E., 1985, Competitive Advantage: Creating and Sustaining Superior Performance. Three Free Press, New York.

21. Rambat, Lupiyoadi. 2015. Praktikum Metode Riset Bisnis. Salemba Empat.Jakarta

22. Rio.W, Susilawati, 2016. Strategi dan Kebijakan Pengembangan UMKM. Refika aditama. Bandung.

23. Solihin, Ismail. 2012. Managemen Strategik. Jakarta. Erlangga.

24. Sugiarto. 2006. "Analisis Hubungan Kausal Antara Lingkungan Perusahaan, Karakteristik Managerial, Strategi Bisnis, Kinerja Industri Kecil: Studi pada Industri Pengolahan Makanan di Provinsi Daerah Istimewa Yogyakarta".

25. Tan Justin. J dan Robert. J. Litschert 1996. "Enviroment strategy relationship and its performance implication: an empirical study of the chinese electronic Industry". Strategic management journal.

26. Wahyudi. A. 1996. Managemen Strategik, Pengantar Proses Berpikir Strategik, Cetakan Pertama, Binarupa Aksara, Jakarta.

27. Zainul Arifin . 2007. "Pengaruh Lingkungan dan Karakteristik Managerial terhadap Strategi Keunggulan Bersaing dan Industri Kecil (Study pada Idustri Kecil Ayaman Bambu Binaan Dinas Perindustrian Dan Perdagangan Provinsi Jawa Timur)". 